\title{
Identification and antimicrobial suceptibility profile of bacteria causing bovine mastitis from dairy farms in Pelotas, Rio Grande do Sul
}

\author{
C. H. Freitas ${ }^{a *}$, J. F. Mendes ${ }^{b}$, P. V. Villarreal ${ }^{a}$, P. R. Santos ${ }^{c}$, C. L. Gonçalves ${ }^{a}$, \\ H. L. Gonzales ${ }^{d}$ and P. S. Nascente ${ }^{e}$
}

a'Laboratório de Micologia e Bioprospecção, Programa de Pós-Graduação em Parasitologia, Departamento de Microbiologia e Parasitologia, Instituto de Biologia, Universidade Federal de Pelotas - UFPel, Av. Eliseu Maciel, CEP 96160-000, Capão do Leão, RS, Brazil

'Programa de Pós-Graduação em Veterinária, Departamento de Veterinária Preventiva, Faculdade de Veterinária, Universidade Federal de Pelotas - UFPel, Av. Eliseu Maciel, CEP 96160-000, Capão do Leão, RS, Brazil

'Laboratório de Micologia e Bioprospecção, Departamento de Microbiologia e Parasitologia, Instituto de Biologia, Universidade Federal de Pelotas - UFPel, Av. Eliseu Maciel, CEP 96160-000, Capão do Leão, RS, Brazil

'Laboratório de Inspeção de Produtos de Origem Animal, Faculdade de Veterinária, Universidade Federal de Pelotas - UFPel, Av. Eliseu Maciel, CEP 96160-000, Capão do Leão, RS, Brazil

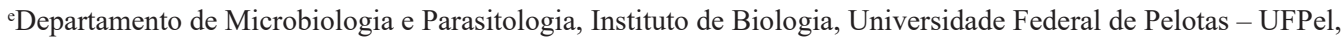
Av. Eliseu Maciel, CEP 96160-000, Capão do Leão, Rio Grande do Sul, Brazil

*e-mail: cristinahallal@live.com

Received: October 18, 2016 - Accepted: May 24, 2017 - Distributed: November 30, 2018

\begin{abstract}
Mastitis is an inflammatory process of the udder tissue caused mainly by the bacteria Staphylococcus aureus. The indiscriminate use of antibiotics fosters conditions that favor the selection of resistant microorganisms, suppressing at the same time susceptible forms, causing a serious problem in dairy cattle. Given the importance in performing an antibiogram to select the most adequate antimicrobial therapy, the aim of this study was to identify bacteria isolated from cow's milk with mastitis, in dairy farms situated in the city of Pelotas, Rio Grande do Sul, and to determinate the susceptibility profile of these isolates against the antibiotics used to treat this illness. A total of 30 isolates of Staphylococcus spp., were selected from milk samples from the udder quarters with subclinical mastitis whose species were identified through the Vitek system. The susceptibility profile was performed by the disk diffusion assay, against: ampicillin, amoxicillin, bacitracin, cephalexin, ceftiofur, enrofloxacin, gentamicin, neomycin, norfloxacin, penicillin G, tetracycline and trimethoprim. In the antibiogram, $100.0 \%$ of the isolates were resistant to trimethoprim and $96.7 \%$ to tetracycline and neomycin, three strains of Staphylococcus spp., (10.0\%) presented resistance to the 12 antibiotics tested and $24(80.0 \%)$ to at least eight. These results showed the difficulty in treating mastitis, due to the pathogens' resistance.
\end{abstract}

Keywords: bovine mastitis, identification of microorganisms, bacterial resistance.

\section{Identificação e perfil de suscetibilidade antimicrobiana de bactérias causadoras de mastite bovina em propriedades leiteiras de Pelotas, Rio Grande do Sul}

\begin{abstract}
Resumo
A mastite se constitui no processo inflamatório da glândula mamária causada principalmente por bactérias Staphylococcus aureus. O uso indiscriminado dos antibióticos promove condições que favorecem a seleção de micro-organismos resistentes e, ao mesmo tempo, suprime formas suscetíveis, causando um grave problema para a bovinocultura leiteira. Tendo em vista a importância da realização do antibiograma para a seleção da terapia antimicrobiana mais adequada, o objetivo deste estudo foi identificar bactérias isoladas de leite de vaca com mastite, oriundas de propriedades leiteiras localizadas na cidade de Pelotas, RS, bem como determinar o perfil de suscetibilidade desses isolados frente a antibióticos usados para o tratamento desta doença. Foram selecionados 30 isolados de Staphylococcus spp. de amostras de leite provenientes de quartos mamários com mastite subclínica, cujas espécies foram identificadas através do sistema Vitek. O perfil de suscetibilidade foi realizado pela técnica de difusão em disco, frente a: ampicilina, amoxicilina, bacitracina, cefalexina, ceftiofur, enrofloxacina, gentamicina, neomicina, norfloxacina, penicilina G, tetraciclina e trimetoprima. No antibiograma,
\end{abstract}


$100,0 \%$ dos isolados foram resistentes a trimetoprima e $96,7 \%$ a tetraciclina e a neomicina, três cepas $(10,0 \%)$ foram resistentes aos 12 antibióticos testados e $24(80,0 \%)$ a pelo menos oito. Esses resultados demonstram a dificuldade encontrada no tratamento da mastite devido à resistência dos agentes patológicos.

Palavras-chave: mastite bovina, identificação de micro-organismos, resistência bacteriana.

\section{Introduction}

Mastitis is an inflammatory process of the udder tissue, which causes high economic losses in dairy cattle, due to the reduction in the milk's quality and production, increasing the use of drugs and the risk of animal death (Melchior et al., 2006). These losses are represented by: $70.0 \%$ due to reduction in the production of the udder quartiles with subclinical mastitis; $14.0 \%$ by the animal's devaluation due to a reduction in the function of the committed quartiles, death or early disposal of the animals; $8.0 \%$ by the loss of the discarded milk by alterations and or by the presence of antibiotic's residuals after treating; $8.0 \%$ due to the economic spending in treatment, veterinary fees and more money expended in medicine (Peres Neto and Zappa, 2011).

The etiology of this disease can be of toxic, traumatic, allergic, metabolic or infectious origin, being infectious the primary causes (Costa, 1998). Though most of the microorganisms can cause infection in the intramammary region, the bacteria specie Staphylococcus aureus is the main pathogen, mainly responsible for the Bovine Chronic mastitis (Roberson et al., 1994). However, due to the diversity of agents that cause mastitis, it is important to identify the etiologic agent of this disease and determinate his susceptibility against antimicrobial agents indicated for treatment, with the purpose to establish a planned therapy with high chances of success (Peixoto et al., 2010).

The antibiotic therapy is the procedure most commonly used to treat bovine mastitis. Studies have suggested a relation between the use of antimicrobial agents in livestock animals and in emergence pathogens of human with a decreased in the susceptibility or completely resistance to antibiotics (Schjørring and Krogfelt, 2011; Landers et al., 2012; Santos, 2010). High levels of multiple resistance represent a potential risk to human health and can difficult the treatment of diseases in animals and humans, exacerbating the curable clinical cases (Ma et al., 2005).

Besides that, the presence of antimicrobial residuals in milk, destined for human consumption represents a growing concern, having in view the bad use of several antibiotics associated to the hygienic management standards and wrong milking conduction. The dissemination of resistant strains between the animals generates a problem to animal health. The antibiotics belong to the group of residuals substances with major influence in milk quality (Mota et al., 2005). There are reports about the occurrence of S. aureus resistant strains to several antibiotics, isolated from cow's milk associated with cases of human infection (Zafalon et al., 2008). This is why it is of extreme importance the isolation and identification of these agents in the laboratory in the disease diagnosis, as the analysis in vitro of the antimicrobial susceptibility in isolated samples, to contribute for a better control using the adequate therapy, and to decrease the antibiotics' resistance.

Therefore, the aim of this study was to identify bacteria isolated from cow's milk with mastitis, in dairy farms situated in the city of Pelotas, Rio Grande do Sul, as to determinate the susceptibility profile of these isolates against the antibiotics commonly used to treat this illness.

\section{Material and Methods}

Visits were accompanied by the Empresa de Assistência Técnica e Extensão Rural- EMATER and the Universidade Federal de Pelotas (UFPel) team of the "Regional project in the development of the bovine dairy culture - importance of the milk quality and good agricultural practice" in 11 dairy farms registered in the program, situated in the city of Pelotas, Rio Grande do Sul, characterized by herds of the Holstein and Jersey breeds. The samples were from the udder quartiles with sub clinical mastitis, verified through the California Mastitis Test (CMT). After their collection performed in the farms, the samples were refrigerated and taken to the Laboratório de Inspeção de Produtos de Origem Animal da Faculdade de Veterinária of the UFPel, where they were seeded in Columbia Agar (enzymatic digest of casein $5 \mathrm{~g}$, enzymatic digest of animal tissue $8 \mathrm{~g}$, enriched peptone $10.0 \mathrm{~g}$, starch $1.0 \mathrm{~g}$, sodium chloride $5.0 \mathrm{~g}$ and agar $14.0 \mathrm{~g}$, manufactured by acumedia ${ }^{\circledR}$ ) with $6.0 \%$ sheep blood by depletion and incubated in a drying oven at $36^{\circ} \mathrm{C}$ for $24 \mathrm{~h}$. After the incubation period, the isolated bacteria were replicated for further identification assays.

The isolated colonies were identified through the hemolysis, Gram stain, Catalase and Coagulase test observation as well through specific biochemical tests For the study's conduction, 30 Staphylococcus spp. isolates were selected. The confirmation of the species was given trough the Vitek ${ }^{\circledR} 2$ Compact system, as reported in the work of Mendes et al. (2016), adapted for bacteria. For the microorganisms' susceptibility profile determination, the Kirb-Bauer disk diffusion technique (Brasil, 2003), was used. The antimicrobials tested were; Ampicillin (AMP), $10 \mu \mathrm{g} / \mathrm{dish}$; Amoxicillin (AMO), $10 \mu \mathrm{g} / \mathrm{dish}$; Bacitracin (BAC), $10 \mu \mathrm{g} / \mathrm{dish}$; Cephalexin (CEF), $30 \mu \mathrm{g} / \mathrm{dish}$; Ceftiofur (CTF), $30 \mu \mathrm{g} / \mathrm{dish}$; Enrofloxacin (ENO), $5 \mu \mathrm{g} / \mathrm{dish}$ ); Gentamicin (GEN), $10 \mu \mathrm{g} /$ dish; Neomycin (NEO), $30 \mu \mathrm{g} / \mathrm{dish}$; Norfloxacin (NOR), $10 \mu \mathrm{g} / \mathrm{dish}$; Penicillin G (PEN), $10 \mu \mathrm{g} / \mathrm{dish}$; Tetracycline (TET), $30 \mu \mathrm{g} / \mathrm{dish}$ and Trimethoprim (TRI), $5 \mu \mathrm{g} / \mathrm{dish}$. 


\section{Discussion and Results}

It was determined that $90.0 \%$ of the Staphylococcus spp., isolates belongs to the specie $S$. aureus, according to Table 1. Though many microorganisms can attack the intramammary region causing infection, $S$. aureus is the principal etiological agent, responsible for the chronic bovine mastitis Medeiros and Souza (2009) analyzed 16 dairy farms, in the region of Cerqueira César, São Paulo, and determined that among the etiological agents with higher frequency in milk samples positive for mastitis, S. aureus presented the $30.0 \%$ In the present study, the high incidence of this specie $(90.0 \%)$ evidence its prevalence in mastitis cases. According to Melo (2008), the prevalence of $S$. aureus, as a bovine mastitis causing agent, can be related to its resistance mechanisms, such as; the presence of biofilm, associated to a reduction of the susceptibility to antimicrobials, to a low healing percentage during lactation and to its presence in the environment, in animals and in humans, considering the fact that these microorganisms are not classified as environmental pathogens. Highly contagious, $S$. aureus is able to cause infections for more than 30 days, dwelling in wounds situated in the udders, hands of milkers and mammary glands of infected cows, leading to high prejudices in the dairy farming, from the direct commitment in the milk's quality to the production's severe lost (Zafalon et al., 2008).

In the present work, the isolates of coagulase-negative staphylococci were identified (Table 1), at species level, being Staphylococcus lentus $(\mathrm{n}=2)$ and Staphylococcus sciuri $(\mathrm{n}=1)$. Raspanti et al. (2015) observed that the coagulase-negative staphylococci species of higher frequency in 219 milk samples with bovine mastitis were; Staphylococcus chromogenes (46.6\%), Staphylococcus haemolyticus (32.0\%), Staphylococcus warmer (7.3\%), Staphylococcus xylosus (6.4\%), Staphylococcus simulans (3.6\%), Staphylococcus epidermidis (2.3\%) and Staphylococcus hycus (1.8\%).

According to Santos (2010), the coagulase-negative staphylococci are part of a very heterogeneous group of microorganisms, related to infections of the bovine's mammary gland, often found in the milking establishments' environment, equipment and udders' skin. The importance of coagulase-negative staphylococci as the predominant pathogens of bovine mastitis has been recognized in recent years. Though coagulase-negative staphylococci species are less virulent than $S$. aureus, these generally

Table 1. Identification of the Staphylococcus spp. species by the Vitek system.

\begin{tabular}{cc}
\hline Identification & $\mathbf{n}(\mathbf{\%})$ \\
\hline S. aureus & $27(90.0)$ \\
S. sciuri & $1(3.3)$ \\
S. lentus & $2(6.7)$ \\
\hline
\end{tabular}

$\mathrm{n}=$ number of isolates. exhibit higher antimicrobial resistance, and more often show multi-antimicrobial resistance (Bansal et al., 2015).

The knowledge of the patterns of antimicrobial resistance is fundamental for the development of effective preventive methods, as for the construction of treatment strategies, when necessaries (Sabour et al., 2004).

In the antiobiogram, $100.0 \%$ of the isolates were resistant to trimethoprim, $96.7 \%$ to tetracycline and neomycin, $90.0 \%$ to cephalexin, $86.7 \%$ to ceftiofur, gentamicin and norflaxacin, $70.0 \%$ to penicillin, $50 \%$ to amoxicillin and $43.3 \%$ to ampicillin, enofloxacin and bacitracin.

According to the literature, S. aureus isolated from bovine mastitis milk presented virulence characteristics and resistance to diverse antibiotics commonly used (Freitas et al., 2005). Many chronic infections caused by this pathogen are related to the biofilm formation; this feature hinders the action of macrophages, and also provides resistance to several antibiotics and promotes the residual persistence of these in the environment (Boyen et al., 2009). In the study conducted by Casanova et al. (2016), thirty-one S. aureus strains isolated from mastitis milk were genotypically tested by the polymerase chain reaction (PCR), giving positive for the icaA gene in $83.87 \%$ of the samples, $80.64 \%$ were positive for the $i c a D$ gene and $74.19 \%$ showed both genes, associated with biofilm formation in S. aureus.

The antibiotic that presented higher action in vitro against bacteria in this study (56.7\%), was the bacitracin. In a recent work published by Bansal et al. (2015), 86.2\% of 129 coagulase-negative Staphylococci strains isolated from subclinical mastitis cases in dairy cows, were highly susceptible to bacitracin.

Penicillin's low susceptibility values, as shown in the antibiogram, were expected, due to its wide spectrum, resulting in its indiscriminate use, encouraging conditions that favors selection of resistant microorganisms, while at the same time suppressing susceptible forms. The resistance found in the penicillin was similar to the found by Zafalon et al. (2008), where they were analyzed 147 milk samples and determinate that the penicillin was the active principle with more resistance $(63.3 \%)$. There are reports of bacterial strains with high prevalence, isolated from cow's milk with mastitis presenting a unique resistance to penicillin (48.3\%) (Zafalon et al., 2008). Fim Júnior et al. (2015) found that $89.2 \%$ and $56.0 \%$ of 69 isolated $S$. aureus samples from mammary quarters of cows with mastitis were resistant to penicillin and ampicillin, respectively.

Costa et al. (2004) showed a high resistance in Staphylococcus spp., isolates of clinical and subclinical mastitis cases to antimicrobials of the beta-lactam penicillin group. These microorganisms produce betalactamases with the ability to cleave the beta-lactam ring of the antimicrobial structure, constituting the main mechanism of resistance. In humans, the bacterial resistance increased in isolated samples of infectious process and it seems to be not only by the bad and intensive use, but also by the 
food transmission of animal origin or by the direct contact with livestock animals (Zafalon et al., 2008).

Staphylococcus spp., in general, presented high resistance to the beta-lactam penicillin antibiotics, above $70.0 \%$ to penicillin $\mathrm{G}$, as well as to ampicillin, amoxicillin and carbenicillin (Tavares, 2000). Against the action of these antibiotics, $70.0 \%$ of Staphylococcus spp., isolates were resistant to penicillin, $40.0 \%$ to ampicillin and $50.0 \%$ to amoxicillin.

Gentamicin presented low susceptibility percentage (13.3\%), although being recognized as an active principle that shows high action against microorganisms related to mastitis. Nader Filho et al. (2007) revealed that the gentamicin was the antibiotic that presented higher (98.6\%) action in vitro against 72 strains of $S$. aureus isolated of mastitis milk analyzed by the authors, meanwhile Freitas et al. (2005) found a lowest value: $49.0 \%(n=59)$ in isolates from samples of cow's milk with mastitis.

In this work, we investigated the sensitivity profile of the isolates in relation to each antibiotic used separately, since antimicrobials with a single mechanism of action are widely used in the treatment of mastitis. However, combined antibiotic therapy may produce synergistic effects in the treatment of bacterial infection and has been shown to delay the emergence of antimicrobial resistance. In the study performed by Medeiros et al. (2009), the association of neomycin + tetracycline + bacitracin was the best treatment for the bacterial isolates obtained from subclinical mastitis, with a percentage of $96.0 \%$ in 291 isolates. According to this author, the associations between different anitmicrobials can potentiate their action, minimized the undesirable effects and increasing the action spectrum over the microorganisms.
In relation to the multiresistance, as presented in the data shown in Table 2, three Staphylococcus spp., strains $(10.0 \%)$ presented resistance to the 12 antibiotics tested, four $(13.3 \%)$ were resistant to 11 and $24(80.0 \%)$ to at least eight, and none of them showed sensitivity to any antimicrobials. Resistance profile to CFE, CTF, GEN, NEO, NOR, TET, TRI at the same time was presented by $16.7 \%$ of the strains (five), while $13.3 \%$ (four) were resistant to BAC, CFE, CTF, GEN, NEO, NOR, PEN, TET, TRI, simultaneously. Similar to the result obtained in the antibiogram of this work, multiresistance characteristics were also identified by Zanette et al. (2010), where from 39 positive $S$. aureus samples, nine (23.07\%) showed multiresistance, varying from three to eight antimicrobials. The multiresistance profile has been reported recently in several countries. In China, for example, Wang et al. (2014) determined that from fifty-three $S$. aureus isolates from mastitis samples, $100 \%$ were resistant to at least one antimicrobial, thirty-three $(62.3 \%)$ to three or more antimicrobials and twenty-five $(47.2 \%)$ to ten or more antimicrobials commonly used. According to the authors, although multifactor in nature, the prevalence of the antibiotic multiresistance of $S$. aureus phenomenon can be due by the extreme, empirical or inappropriate use of antimicrobial drugs as the treatment for dairy diseases.

The resistance's profile presented by the bacteria studied is an important concern, because the antibiotics available in the market do not show any significant effect against such microorganisms, the treatment of ill animals is getting more difficult and, consequently, aggravates the economic losses resulting by mastitis.

Table 2. In vitro resistance profile of isolated bacteria from bovine mastitis against antibiotics used for treatment.

\begin{tabular}{ll}
\hline \multicolumn{1}{c}{ Antibiotics } & n (\%) \\
\hline AMP, AMO, BAC, CFE, CTF, ENO, GEN, NEO, NOR, PEN, TET, TRI & $3(10.0)$ \\
AMP, AMO, BAC, CFE, CTF, GEN, NEO, NOR, PEN, TET, TRI & $4(13.3)$ \\
BAC, CFE, CTF, ENO, GEN, NEO, NOR, PEN, TET, TRI & $2(6.6)$ \\
AMO, BAC, CFE, CTF, GEN, NEO, NOR, PEN, TET, TRI & $1(3.3)$ \\
AMP, AMO, BAC, CFE, CTF, ENO, NEO, PEN, TET, TRI & $1(3.3)$ \\
AMP, AMO, BAC, CFE, CTF, NEO, PEN, TET, TRI & $2(6.7)$ \\
AMO, BAC, CFE, GEN, NEO, NOR, PEN, TET, TRI & $1(3.3)$ \\
BAC, CFE, CTF, GEN, NEO, NOR, PEN, TET, TRI & $4(13.3)$ \\
AMP, AMO, BAC, CFE, CTF, ENO, GEN, NOR, TRI & $1(3.3)$ \\
AMO, CFE, ENO, GEN, NEO, NOR, PEN, TET, TRI & $1(3.3)$ \\
AMP, AMO, ENO, NEO, NOR, PEN, TET, TRI & $1(3.3)$ \\
CFE, CTF, ENO, GEN, NEO, NOR, TET, TRI & $1(3.3)$ \\
BAC, CFE, ENO, GEN, NEO, NOR, TET, TRI & $1(3.3)$ \\
BAC, ENO, CTF, GEN, NEO, PEN, TET, TRI & $1(3.3)$ \\
BAC, ENO, CTF, GEN,NEO,NOR,TET,TRI & $1(3.3)$ \\
CFE, CTF, GEN, NEO, NOR, TET, TRI & $5(16.0)$ \\
\hline
\end{tabular}

$\mathrm{n}=$ number of multiresistance bacteria; $\mathrm{AMP}=$ ampicillin; $\mathrm{AMO}=$ amoxicillin; $\mathrm{BAC}=$ bacitracin; $\mathrm{CFE}=$ cephalexin; $\mathrm{CTF}=$ ceftiofur; $\mathrm{ENO}=$ enrofloxacin $; \mathrm{GEN}=$ gentamicin; $\mathrm{NEO}=$ neomycin $; \mathrm{NOR}=$ norfloxacin $; \mathrm{PEN}=$ penicilin; $\mathrm{TET}=$ tetracycline; $\mathrm{TRI}=$ trimethoprim . 


\section{Conclusion}

The identification of the isolated bacteria species from cow's milk with mastitis demonstrated that $90.0 \%(n=27)$ of the Staphylococcus spp., strains belonged to the specie $S$. aureus, being the main etiological agent responsible for this illness.

The resistance's profile presented by the studied bacteria is an important concern, alarming consequential economic losses in dairy cattle and healthy problems in both animals and humans, once its virulence characteristics, contribute to the resistance and the inadequate use of antibiotics, provides the appearance of multiresistant strains, compromising the its efficacy.

\section{References}

BANSAL, B.K., GUPTA, D.K., SHAFI, T.A. and SHARMA, S., 2015. Comparative antibiogram of coagulase-negative Staphylococci (CNS) associated with subclinical and clinical mastitis in dairy cows. Veterinary World, vol. 8, no. 3, pp. 421-426. PMid:27047108. http://dx.doi.org/10.14202/vetworld.2015.421-426.

BOYEN, F., EECKHAUT, V., VAN IMMERSEEL, F., PASMANS, F., DUCATELLE, R. and HAESEBROUCK, F., 2009. Quorum sensing in veterinary pathogens: mechanisms, clinical importance and future perspectives. Veterinary Microbiology, vol. 135, no. 3-4, pp. 187-195. PMid:19185433. http://dx.doi.org/10.1016/j. vetmic.2008.12.025.

BRASIL. Agência Nacional de Vigilância Sanitária, 2003. Padronização dos testes de sensibilidade a antimicrobianos por disco-difusão: norma aprovada. 8. ed. Rio de Janeiro: ANVISA.

CASANOVA, V.P., APPIO, J., KOHL, E., MICHAELSEN, T.R., PAIM, D.S., BRUNETTO, T.R., PELLEGRINI, D.D.C.P., BENNEMANN, P.E., COLLET, S.G. and GIRARDINI, L.K., 2016. Bovine mastitis: prevalence and antimicrobial susceptibility profile and detection of genes associated with biofilm formation in Staphylococcus aureus. Semina: Ciências Agrárias, vol. 37, no. 3, pp. 1369-1378. http://dx.doi.org/10.5433/1679-0359.2016v37n3p1369.

COSTA, E.O., 1998. Importância da mastite na produção leiteira do país. Revista da Educação Continuada do CRMV-SP, v. 1, n. 1, p. 3-7.

COSTA, E.O., GARINO JUNIOR, F., RIBEIRO, A.R., WATANABE, E.T., MELVILLE, P.A. and BENITES, N.R., 2004. Resistência aos antimicrobianos de microrganismos do gênero Staphylococcus isolados de mastite bovina no decênio de 1992 a 2001. Revista Napgama, vol. 7, no. 2, pp. 13-20.

FIM JÚNIOR, G.A., VASO, C.O., SEIXAS, A.B., LOPES, N.S.S., PILON, L.E., SANTANA, R.C.M., LANGE, C.C. and ZAFALON, L.F., 2015. Sensibilidade antimicrobiana de Staphylococcus aureus isolados de amostras de leite de vacas com mastite subclínica. Ars Veterinária, vol. 31, no. 2, pp. 117. http://dx.doi.org/10.15361/2175-0106.2015v31n2p117.

FREITAS, M.F.L., PINHEIRO JUNIOR, J.W., STAMFORD, T.L.M., RABELO, S.S.A., SILVA, D.R., SILVEIRA FILHO, V.M., SANTOS, F.G.B. and MOTA, R.A., 2005. Perfil de sensibilidade antimicrobiana in vitro de Staphylococcus coagulase positivos isolados de leite com mastite no agreste do Estado de Pernanbuco. Arquivos do Instituto Biológico, v. 72, n. 2, p. 171-177.

LANDERS, T.F., COHEN, B., WITTUM, T.E. and LARSON, E.L., 2012. A review of antibiotic use in food animals: perspective, policy, and potencial. Public Health Reports, vol. 127, no. 1, pp. 4-22. PMid:22298919. http://dx.doi.org/10.1177/003335491212700103.

MA, E., WONG, C., LAI, K., CHAN, E., YAM, W.C. and CHAN, A., 2005. Kocuria kristinae infection associated with acute cholecystitis. BMC Infectious Diseases, vol. 5, no. 1, pp. 60. http://dx.doi.org/10.1186/1471-2334-5-60.

MEDEIROS, E.S., MOTA, R.A., SANTOS, M.V., FREITAS, M.F.L., PINHEIRO JÚNIOR, J.W. and TELES, J.A.A., 2009. Perfil de sensibilidade microbiana in vitro de linhagens de Staphylococcus spp. isoladas de vacas com mastite subclínica. Pesquisa Veterinária Brasileira, vol. 29, no. 7, pp. 569-574. http:// dx.doi.org/10.1590/S0100-736X2009000700012.

MEDEIROS, M.I.M. and SOUZA, L.C., 2009. Associação de agentes patogênicos isolados em análise microbiológica da água, com a presença de mastite clinica ou subclínica, em vacas de propriedades leiteiras da Região de Cerqueira César-SP. Ciência e Agrotecnologia, vol. 33, no. 2, pp. 580-585.

MELCHIOR, M.B., FINK-GREMMELS, J. and GAASTRA, W., 2006. Comparative assessment of the antimicrobial susceptibility of Staphylococcus aureus isolates from bovine mastitis in biofilm versus planktonic culture. Journal of Veterinary Medicine. B, Infectious Diseases and Veterinary Public Health, vol. 53, no. 7, pp. 326-332. PMid:16930277. http://dx.doi.org/10.1111/j.14390450.2006.00962.x.

MELO, P.C., 2008. Estudo fenotípico e genotípico da produção de biofilmes por estirpes de Staphylococcus aureus isoladas dos casos de mastite subclínica bovina. Jaboticabal: Universidade Estadual Paulista Júlio de Mesquita Filho, 200 p. Dissertação de Mestrado em Medicina Veterinária Preventiva.

MENDES, J.F., GONÇALVES, C.L., FERREIRA, G.F., ESTEVES, I.A., FREITAS, C.H., VILLARREAL, P.J.V., MELLO, J.R.B., MEIRELES, M.C.A. and NASCENTE, P.S., 2016. Antifungal susceptibility profile of diferent yeasts isolates from wild animals, cow's milk with subclinical mastitis and hospital environment. Brazilian Journal of Biology $=$. Revista Brasileira de Biologia. PMid:28699964. http://dx.doi.org/10.1590/1519-6984.04916.

MOTA, R.A., SILVA, K.P.C., FREITAS, M.F., PORTO, J.N. and SILVA, L.B., 2005. Utilização indiscriminada de antimicrobianos e sua contribuição a multirresistência bacteriana. Brazilian Journal of Veterinary Research and Animal Science, vol. 42, no. 6, pp. 465-470. http://dx.doi.org/10.11606/issn.1678-4456. bjvras.2005.26406.

NADER FILHO, A., FERREIRA, L.M., AMARAL, L.A. and OLIVEIRA, R.P., 2007. Sensibilidade antimicrobiana dos Staphylococcus aureus isolados no leite de vacas com mastite. Arquivos do Instituto Biologico, vol. 74, no. 1, pp. 1-4.

PEIXOTO, R.M., FRANÇA, C.A., SOUZA JÚNIOR, A.F., VESCHI, J.L.A. and COSTA, M.M., 2010. Etilogia e perfil de sensibilidade antimicrobiana dos isolados bacterianos de mastite em pequenos ruminantes e concordância de técnicas empregadas no diagnostico. Pesquisa Veterinária Brasileira, vol. 30, no. 9, pp. 735-740. http://dx.doi.org/10.1590/S0100-736X2010000900005.

PERES NETO, F. and ZAPPA, V., 2011. Mastite em vacas leiteiras. Revista Científica Eletrônica de Medicina Veterinária, vol. 9 , no. 16 .

RASPANTI, C.G., BONETTO, C.C., VISSIO, C., PELLEGRINO, M.S., REINOSO, E.B., DIESER, S.A., BOGNI, C.I., LARRIESTRA, A.J. and ODIERNO, L.M., 2015. Prevalence and antibiotic susceptibility of coagulase-negative Staphylococcus species from bovine subclinical mastitis in dairy herds in the central 
region of Argentina. Revista Argentina de Microbiologia, vol. 48, no. 1, pp. 50-56. PMid:26935912. http://dx.doi.org/10.1016/j. ram.2015.12.001.

ROBERSON, J.R., FOX, L.K., HANCOCK, D.D., GAY, J.M. and BESSER, T.E., 1994. Ecology of Staphylococcus aureus isolated from various sites on dairy farms. Journal of Dairy Science, vol. 77, no. 11, pp. 3354-3364. PMid:7814712. http:// dx.doi.org/10.3168/jds.S0022-0302(94)77277-5.

SABOUR, P.M., GILL, J.J., LEPP, D., PACAN, J.C., AHMED, R., DINGWELL, R. and LESLIE, K., 2004. Molecular typing and distribution of Staphylococcus aureus isolates in Eastern Canadian Dairy Herds. Journal of Clinical Microbiology, vol. 42, no. 8, pp. 3449-3455. PMid:15297482. http://dx.doi.org/10.1128/ JCM.42.8.3449-3455.2004.

SANTOS, L.L., 2010. Perfil etiológico da mastite bovina na bacia leiteira de Santa Izabel do Oeste, Paraná. Ciência Animal Brasileira, vol. 11, no. 4, pp. 860-866.

SCHJØRRING, S. and KROGFELT, K. A., 2011. Assessment of Bactericidal antibiotic resistance transfer in the Gut. International Journal of Microbiology, vol. 2011, pp. 312956. PMid:21318188. http://dx.doi.org/10.1155/2011/312956.
TAVARES, W., 2000. Bactérias gram-positivas problemas: resistência do estafilococo, do enterococo e do pneumococo aos antimicrobianos. Revista da Sociedade Brasileira de Medicina Tropical, vol. 33, no. 3, pp. 281-301. PMid:10967598. http:// dx.doi.org/10.1590/S0037-86822000000300008.

WANG, X., WANG, X., WANG, Y., GUO, G., USMAN, T., HAO, D., TANG, X., ZHANG, Y. and YU, Y., 2014. Antimicrobial resistance and toxin gene profiles of Staphylococcus aureus strains from Holstein milk. Letters in Applied Microbiology, vol. 58, no. 6, pp. 527-534. PMid:24460961. http://dx.doi.org/10.1111/lam.12221.

ZAFALON, L.F., ARCARO, J.R.P., NADER FILHO, A., FERREIRA, L.M., CASTELANI, L. and BENVENUTOO, F., 2008. Investigation og the antimicrobial resistance patterns in Sthaphylococcus aureus isolated in the milking of cows in the lactation. Revista do Instituto Adolfo Lutz, vol. 67, no. 2, pp. 118-125.

ZANETTE, E., SCAPIN, D., and ROSSI, E.M., 2010. Suscetibilidade antimicrobiana de Staphylococcus aureus isolados de amostras de leite de bovinos com suspeita de mastite. Unoesc \& Ciência-ACBS, vol. 1, no. 1, pp. 65-70. 